\title{
66 \\ La place des parents dans la résilience familiale. Une métasynthèse qualitative
}

The parents' significance in family resilience. A qualitative metasynthesis

Céline DUJARDIN ${ }^{1}$, Dieter FERRING ${ }^{1}$ et Willy LAHAYE ${ }^{2}$

1. Integrative Research Unit on Social and Individual Development, Université du Luxembourg, Luxembourg

2. Département d'Études et d'Actions Sociales - Service des Sciences de la Famille, Université de Mons, Belgique 
La place des parents dans la résilience familiale. Une métasynthèse qualitative

En employant une méthode de métasynthèse qualitative, l'article identifie à travers la littérature francophone, germanophone et anglophone les différentes conceptions de résilience familiale. Le rôle attribué au parent dans ce processus est également examiné en fonction de cette revue de la littérature. En outre, le travail de synthèse tient compte des différents contextes d'investigation de la résilience familiale, mais aussi de la finalité poursuivie par les publications examinées. Les résultats débouchent sur une discussion relative à la qualité de l'éducation parentale et aux contextes d'intervention dans le cadre de l'éducation familiale.

The parents' significance in family resilience. A qualitative metasynthesis

the article identifies the conceptions of family resilience while questioning the role associated to the parent in this process. Further, the synthesis work takes stock about the investigated contexts of family resilience, but also on the intended purpose of the trilingual publications examined. The results lead to the discussion of the quality of parenting and the context of intervention around family education. Finally, the conclusion summarizes the main reflections and findings of the study on the place of the parent in the family resilience.

\section{Der Stellenwert der Eltern in der Familienresilienz. Eine qualitative Metasynthese}

In einer Auswahl französisch-, deutsch- und englischsprachiger Publikationen werden Konzeptionen der familialen Resilienz und der Rolle der Eltern innerhalb dieses Prozesses über eine qualitative Meta-Synthese analysiert. Zudem werden Kontexte der Familienresilienz mit Blick auf unterschiedliche Zielsetzungen der untersuchten Publikationen reflektiert. In der Diskussion der Ergebnisse wird familiale Resilienz in Bezug zu der Qualität der elterlichen Erziehung gesetzt und Konsequenzen für die Intervention in Familien angesprochen.

La correspondance pour cet article doit être adressée à Céline Dujardin, Faculté des Lettres, des Sciences Humaines, des Arts et des Sciences de I'Education, Campus Walferdange, Université du Luxembourg, Route de Diekirch, 7220 Walferdange, Luxembourg ou par courriel à <celine.dujardin@uni.lu> . 